\title{
Locus of control, academic self-concept, and academic dishonesty among high ability college students
}

\begin{abstract}
Anne N. Rinn, ${ }^{1}$ Janette Boazman, ${ }^{2}$ Ann Jackson, ${ }^{1}$ and Brenda Barrio ${ }^{1}$
Abstract: The purposes of the current study were to evaluate a measure of academic dishonesty and examine high ability college students' loci of control and its effect on behaviors of academic dishonesty, as moderated by academic self-concept. A total of 357 high ability college students enrolled at two universities in the southwestern United States took part in this study. Variables and the moderation of academic self-concept were examined for the aggregate group $(n=357)$ and for the disaggregate honors and non-honors groups. Students completed the Rotter Internal-External Locus of Control Scale (Rotter, 1966), the Self-Description Questionnaire III (Marsh, 1989), and a scale to measure academic dishonesty based on the work of Geddes (2011). A 17-item measure of academic dishonesty was developed. Results indicate locus of control does not significantly predict academic dishonesty for the non-honors group, but several relationships were found among variables for the aggregate group and for the honors and non-honors groups.
\end{abstract}

Keywords: locus of control, academic self-concept, academic dishonesty, gifted college students

Many researchers have studied locus of control, or a person's belief about how much control he or she has over events in his or her life (Lefcourt, 1966; Rotter, 1966). Starting several decades ago, researchers began applying the concept of locus of control to the academic setting (for reviews, see Findley \& Cooper, 1983; Kirkpatrick, Stant, Downes, \& Gaither, 2008; Mehta, 2009; Prihadi \& Hairul, 2011). This research has generally indicated that an individual's locus of control leads to different reactions in various situations, including academic settings (Keith, Pottebaum, \& Eberhardt, 1986). Little research, though, has examined the role of locus of control among high ability students (Assouline, Colangelo, Ihrig, \& Forstadt, 2006; Siegle, Rubenstein, Pollard, \& Romey, 2010). Because having an internal locus of control and academic success (e.g., learning, high grades) are related (Keith et al., 1986), more research is needed to examine the loci of control of high ability and academically successful (or unsuccessful) students.

Little to no research exists regarding the relationship between locus of control and academic dishonesty, or cheating, among high ability students (see Geddes, 2011). A relationship between locus of control and academic dishonesty has been found among average ability samples, though, whereby those with an external locus of control are more likely to engage in academic dishonesty than those with an internal locus of control (Gallagher, 2010; Karabenik \& Srull, 1978; Pino \& Smith, 2003; Rettinger \& Kramer, 2009). Other variables may influence the relationship between locus of control and academic dishonesty, too, such as personal expertise, anticipated elation, and anticipated regret (Sierra \& Hyman, 2006). Among high ability samples in particular, academic self-concept, or one's feelings about his or her own academic abilities

\footnotetext{
${ }^{1}$ Department of Educational Psychology, University of North Texas, 1155 Union Circle \#311335, Denton, TX 76203, anne.rinn@unt.edu

${ }^{2}$ Department of Education, University of Dallas
} 
(Marsh \& Shavelson, 1985), may influence the relationship between locus of control and academic dishonesty. These achievement-related beliefs, namely locus of control and academic self-concept, affect academic outcomes, including academic dishonesty.

Research generally indicates an external locus of control is negatively related to selfesteem (Benson et al., 1994; Downs \& Rose, 1991; Smith, Sapp, Farrell, \& Johnson, 1998), and, in an academic setting, an internal locus of control is related to a higher academic self-concept (Anazonwu, 1995; Gadzella, Williamson, \& Ginther, 1985). In other words, those who take ownership of their successes and failures have stronger feelings about their own academic abilities. Further, research indicates that those with a higher academic self-concept are less likely to engage in academic dishonesty (Murdock \& Anderman, 2006). Thus, because high ability students typically have higher academic self-concepts and a more internal locus of control than average ability students (Litster \& Roberts, 2011; Siegle \& Reis, 1998), they may be less likely to engage in academic dishonesty. Therefore, the purpose of this study is to evaluate a measure of academic dishonesty for use with high ability college students and to explore the relationship between achievement-related beliefs, namely locus of control and academic self-concept, and academic dishonesty among high ability college students.

\section{Locus of Control}

Locus of control stems from social learning theory (Rotter, 1954) and Weiner's (1974, 1985) attribution theory, and refers to a person's perception about the underlying root causes of successes or failures in his or her life (Heider, 1958; Lefcourt, 1966; Rotter, 1966; 1975; Weiner, 1974). When individuals most often believe their successes and failures are due to factors within their control, they are viewed as having an internal locus of control (i.e., success or failure happened because of effort the individual put forward or did not put forward). If individuals most often believe their successes and failures are due to something outside of their control (i.e., success or failure happened because of luck or task difficulty), they are regarded as having an external locus of control. For extensive reviews of the literature on locus of control and attribution theory, see Assouline et al. (2006), Carton and Nowicki (1994), Findley and Cooper (1983), and Lefcourt (1982).

Attribution interpretations can lead to both positive and negative reactions. For example, if an individual interprets a failure as the result of too little effort (an internal locus of control), he or she likely believes that increased effort will make a positive change in the outcome. Those with an internal locus of control are more likely to strive for achievement, work to improve their situation, apply what they learn toward positive outcomes for the future, and persist in the face of failure (Findley \& Cooper, 1983). Conversely, if an individual interprets a failure as the result of a difficult exam or an unfair instructor (an external locus of control), he or she may believe that his or her performance is due to factors beyond his or her control and may not see any reason to hope for future improvements.

While there are advantages and disadvantages to having an internal or external locus of control in different settings, many psychologists and researchers agree that having an internal locus of control is ultimately the healthier attribute (Crandall \& Crandall, 1983). Studies conducted with college students indicate those students with an internal locus of control show more success in adjustment to college life than those with an external locus of control (Martin \& Dixon, 1994), those students with an internal locus of control had above average college course grades (Kirkpatrick et al., 2008), and an internal locus of control generally predicts greater

Journal of the Scholarship of Teaching and Learning, Vol. 14, No. 4, October 2014. 
academic success overall (Carden, Bryant, \& Moss, 2004; Keith et al., 1986). Further, when college students move from an external to an internal locus of control their grades tend to improve (Noel, Forsyth, \& Kelley, 1987),

Locus of control and high ability students. Most research indicates high ability and gifted students have an internal locus of control (Assouline et al., 2006; Collier, Jacobson \& Stahl, 1987; Harty, Adkins, \& Hungate, 1984; Heller \& Ziegler, 1996; Laffoon, JenkinsFriedman, \& Tollefson, 1989; Morrow, 1989; Siegle \& Reis, 1998; Siegle et al., 2010; Yong, 1994), with locus of control becoming more internal through the school years and beyond (Karnes \& D'Ilio, 1991; Kormanik \& Rocco, 2009). Laffoon et al. (1989) indicate high achieving gifted students had a significantly higher internal locus of control than both underachieving gifted and non-gifted students. Similarly, research has shown that high achievers have higher internal locus of control scores than underachievers (Kanoy, Johnson, \& Kanoy, 1980; Knight, 1995). An external locus of control may be associated with classroom stress and classroom burnout (Fimian \& Cross, 1986), which could also lead to underachievement.

Chan (1996) found that high ability students often perceive themselves to be cognitively competent and therefore are less likely to attribute failures to a lack of ability than their averageachieving peers. Further, high ability students had more confidence in their own personal control over successes and failures in their school coursework than their average ability peers. In other words, gifted students tended to believe they have more control over their coursework due to the fact that they could control the learning strategies they used and the amount of effort they put in to their work.

Within the gifted population, level of ability may play a role in individual locus of control. In a study of highly, moderately, and mildly mathematically gifted Finnish adolescents and adults, Nokelainen, Tirri, and Merenti-Välimäki (2007) found that highly and moderately mathematically gifted individuals believe ability is more important for success than effort, while mildly mathematically gifted individuals believe effort is more important for success. In addition, moderately and mildly mathematically gifted individuals believe a lack of effort causes failure, while highly mathematically gifted individuals believe a lack of ability causes failure.

Locus of control and academic dishonesty. Engaging in academic dishonesty, or the deliberate use of someone else's information in work submitted for academic credit (Pavela, 1997), likely depends somewhat on one's locus of control (Sierra \& Hyman, 2006). Believing that successes or failures are out of one's control may result in academic dishonesty. "Cheaters tend to consider their behavior acceptable when they can describe it as caused by external forces rather than their own dishonesty" (Rettinger \& Kramer, 2009, p. 295). For example, believing that an exam will be so difficult that it is impossible to pass may lead some students to engage in academically dishonest behavior (i.e., cheating rather than studying).

Some researchers have found significant results regarding the relationship between academic dishonesty and an external locus of control (Gallagher, 2010; Karabenick \& Srull, 1978; Lefcourt, 1982; Pino \& Smith, 2003). Alarape and Onakoya (2003) examined the cheating behaviors and personality variables, including locus of control, of Nigerian college students. They report that students with an external locus of control reported more cheating behaviors. In addition to actual behavior, locus of control affects attitudes toward cheating and unethical behavior in the classroom. Trevino and Youngblood (1990) found American graduate students who had an internal locus of control were less likely to engage in unethical behavior. In a study of American undergraduates, Coleman and Mahaffey (2000) found similar results: those with an external locus of control viewed cheating as more acceptable than those with an internal locus of 
control. On the contrary, Whitley (1998), in his meta-analysis of academic dishonesty among college students, found cheating was slightly correlated with an internal locus of control. Further examination by Whitley revealed "students with an internal control are more likely to cheat on a task when they think the outcome is based on skill rather than chance, and the opposite is true of those with an external locus of control" (p. 251).

\section{Academic Dishonesty}

Academic dishonesty among college students has reached epidemic proportions (Arvidson, 2004; McCabe, Trevino, \& Butterfield, 2001). In fact, according to the Center for Academic Integrity (2007), approximately $85 \%$ of students surveyed admitted to cheating at least once. Similarly, a national survey published in Education Week showed that $54 \%$ of students admitted to plagiarizing from the internet, $74 \%$ of students admitted to a serious cheating offense at least once during the last school year, and $47 \%$ of students believe their teachers sometimes choose to ignore when they saw students cheat (What is plagiarism?, n.d.). Research also indicates some specific forms of cheating have increased over the last several decades (Vandehey, Diekhoff, \& LaBeff, 2007), particularly those that involve technology and the Internet (Jones, 2011). Many students even feel justified in cheating under certain circumstances, such as when students do not believe their cheating will affect others (LaBeff, Clark, Haines, \& Diekhoff, 1990).

Academic dishonesty impedes learning (Gardner \& Melvin, 1988) and compromises the assessment of student learning (West, Ravenscroft, \& Shrader, 2004), such that educators cannot adequately assess student learning if no learning has occurred. Further, academic dishonesty is a high-risk behavior for college students because being caught cheating can have devastating effects, including probation, suspension, or expulsion from school.

What would lead someone to cheat if the consequences are so great? Rettinger and Kramer (2009) separated the reasons for cheating into three categories; 1) student motivation (intrinsic or extrinsic), 2) neutralizing attitudes (e.g., "no one else is hurt if I cheat", p. 299), and 3) perceptions that others were cheating. Owunwanne, Rustagi, and Dada (2010) suggest the following reasons for cheating also play an important part in the causes of academic dishonesty: "pressure from peers, lack of preparedness, unrealistic expectations and the emphasis on success ... emphasis on higher grades for impressive transcripts, scholarship opportunities and possible Graduate Assistantships" (p. 61). The reasons for academic dishonesty are varied and extensive, suggesting more research is needed to understand precursors to this behavior.

Academic dishonesty and high ability students. Few research studies have been published on academic dishonesty and high ability students (Abilock, 2009), perhaps because higher academic achievement and stronger beliefs in one's abilities (academic self-concept) are consistently related to lower levels of academic dishonesty (Haines, Diekhoff, LaBeff, \& Clark, 1986; McCabe \& Trevino, 1997; Whitley, 1998). In fact, research indicates there is a significant negative relationship between grade point average and academic dishonesty (Antion \& Michael, 1983; Crown \& Spiller, 1998; Singhal, 1982). And, research on college students shows less able students are more likely to cheat than more able students (Newstead, Franklyn-Stokes, \& Armstead, 1996).

Yet, because of the vast numbers of college students who admit to behaviors of academic dishonesty, it is logical to assume that some high ability college students are also engaging in academic dishonesty, particularly given the emphasis on academic performance within this 
population (Abilock, 2009). Research on high ability students and academic dishonesty has shown that these students' motivation to cheat was attributed to grades and grade point average pressure, peer pressure, and the demands of a heavy workload (Geddes, 2011).

\section{Academic Self-Concept}

Self-concept can be defined as "a person's perceptions of him- or herself ... formed through experience with and interpretations of one's environment" (Marsh \& Shavelson, 1985, p. 107). Self-concept is both multifaceted "in that people categorize the vast amount of information they have about themselves and relate these categories to one another", and is hierarchically arranged "with perceptions of behavior at the base moving to inferences about self in sub areas (e.g., academic-English, science, history, mathematics), then to inferences about self in general" (Marsh \& Shavelson, p. 107; Shavelson, Hubner, \& Stanton, 1976). Academic self-concept can be defined as a person's perceptions about him- or herself related to his or her academic abilities.

A student's academic self-concept is especially important to his or her success in school and this is particularly true when it comes to high ability students (Rinn, Plucker, \& Stocking, 2010). For example, Lent, Brown, and Gore (1997) found that academic self-concept was a significant predictor of students' academic achievement (i.e., grade point average) in college. The academic self-concepts of high ability college students also likely affect such areas as educational aspirations, career aspirations, and retention, in addition to academic achievement (Rinn, 2005; 2007).

Academic self-concept and high ability students. Gifted and high ability students usually differ from average ability students with respect to their self-concepts, particularly in the area of academic self-concept (Pyryt \& Mendaglio, 1994). Relative to average-ability students, gifted students typically have higher academic self-concepts (Ablard, 1997; Colangelo, Kelly, \& Schrepfer, 1987; Litster \& Roberts, 2011). Research has shown that honors college students have considerable confidence in their academic abilities (Mathiasen, 1985). Further, research indicates high ability college students enrolled in an honors program have higher academic self-concepts than their equally able peers who are not enrolled in an honors program (Rinn, 2007).

\section{Relationship between Locus of Control, Academic Self-Concept, and Academic Dishonesty}

Achievement-related beliefs, such as locus of control and academic self-concept, are likely to influence one's decision to engage in academic dishonesty. Attributions for success or failure, whether they be internal or external, are one piece of information that students use to make appraisals regarding their academic abilities and to form their academic self-concepts (Marsh, 1986; Pyryt \& Mendaglio, 1994; Schunk, 1991; Siegle et al., 2010). Belief in one's academic ability (academic self-concept) may cause a student to believe they have the ability be successful, which could deter that student from academically dishonest behavior (Murdock \& Anderman, 2006).

\section{The Current Study}

The current study assesses a measure of academic dishonesty and also examines high ability college students' loci of control and its relationship to behaviors of academic dishonesty, as moderated by academic self-concept. The researchers examine a sample of 357 high ability 
students from two universities, and two subsamples, honors students and non-honors students (see Table 1). Membership in an honors program has potentially greater consequences for academic dishonesty (e.g., being kicked out of the program, losing scholarships). Because those

Table 1

Descriptive Statistics for Participants

\begin{tabular}{|c|c|c|c|c|c|}
\hline Variable & $\begin{array}{l}\text { Whole-Group } \\
\qquad(\mathrm{n}=357)\end{array}$ & $\begin{array}{l}\text { University } \\
A(n=137)\end{array}$ & $\begin{array}{l}\text { University } \\
B(n=220)\end{array}$ & $\begin{array}{l}\text { Honors } \\
(\mathrm{n}=179)\end{array}$ & $\begin{array}{c}\text { Non- } \\
\text { honors } \\
(n=178)\end{array}$ \\
\hline Mean age (yrs.) & 19.87 & 19.84 & 19.73 & 19.62 & 20.05 \\
\hline \multicolumn{6}{|l|}{ Gender } \\
\hline Male & $32.3 \%$ & $35.5 \%$ & $28.5 \%$ & $37.4 \%$ & $28.1 \%$ \\
\hline Female & $63.3 \%$ & $61.0 \%$ & $69.3 \%$ & $57.5 \%$ & $70.8 \%$ \\
\hline transgender & $0.5 \%$ & $0.0 \%$ & $1.5 \%$ & $0.6 \%$ & $0.6 \%$ \\
\hline Non-responders & $2.1 \%$ & $3.6 \%$ & $.7 \%$ & $4.5 \%$ & $0.6 \%$ \\
\hline \multicolumn{6}{|l|}{ Ethnicity } \\
\hline Caucasian & $74.2 \%$ & $73.7 \%$ & $77.9 \%$ & $73.7 \%$ & $77.5 \%$ \\
\hline Biracial/Multiracial & $7.9 \%$ & $6.6 \%$ & $8.6 \%$ & $6.7 \%$ & $8.4 \%$ \\
\hline Hispanic & $7.5 \%$ & $6.6 \%$ & $7.7 \%$ & $6.1 \%$ & $8.4 \%$ \\
\hline Asian & $5.7 \%$ & $7.3 \%$ & $4.1 \%$ & $6.7 \%$ & $3.9 \%$ \\
\hline $\begin{array}{l}\text { African American } \\
\text { American }\end{array}$ & $1.9 \%$ & $4.4 \%$ & $.9 \%$ & $4.5 \%$ & $0.0 \%$ \\
\hline $\begin{array}{l}\text { Indian/Alaska } \\
\text { Native }\end{array}$ & $0.3 \%$ & $0.7 \%$ & $0.0 \%$ & $0.6 \%$ & $0.0 \%$ \\
\hline $\begin{array}{l}\text { Native Hawaiian or } \\
\text { other Pacific } \\
\text { Islander }\end{array}$ & $0.3 \%$ & $0.0 \%$ & $.5 \%$ & $0.0 \%$ & $0.6 \%$ \\
\hline Non-responders & $2.7 \%$ & $0.7 \%$ & $1.4 \%$ & $1.1 \%$ & $1.1 \%$ \\
\hline
\end{tabular}

high ability students who chose to apply for membership to an honors program might have higher academic self-concepts than equally able students who do not choose to apply for membership to an honors program (Rinn, 2007), membership in an honors program might affect the relationship between locus of control and academic dishonesty among equally able college students. Gaining a more complete understanding of high ability college students' achievementrelated beliefs (academic self-concepts and loci of control) could enhance academic dishonesty research (Arvidson, 2004), inform policy regarding academic dishonesty on university campuses, and provide information to academic advisors and professors who work with high ability college students, whether they are enrolled in an honors program or not.

\section{Method}

\section{Participants}

Participants for the current study include high ability college students from two universities in the southwestern United States. University A is a public, research university with an enrollment of about 28,325 undergraduates and 7,429 graduate students. University B is a private, religious, co-educational, liberal arts university with an enrollment of about 1,337 
undergraduate students and 1,506 graduate students. An e-mail was sent to all honors students at University A $(n=1,100)$ and at University B $(n=1,112)$ that invited them to participate in an online research study regarding college student experiences. These students had SAT scores above 1200 or ACT scores above 27. Both universities have honors programs, but not all high ability students enrolled in honors classes participate in the honors programs, resulting in a sample of both honors and non-honors students. The participants who responded resulted in a convenience sample. Participants were asked to electronically sign an informed consent document and then complete a series of online questionnaires.

Students designated to the "honors" group were members of an honors program and had a combined SAT score of 1200 or greater (old version) or 1800 or greater (new version), or an ACT score of 27 or greater. The honors group is comprised of students from both universities. Students who were designated to the "non-honors" group were not members of an honors program, but had a combined SAT score of 1200 or greater (old version) or 1800 or greater (new version), or an ACT score of 27 or greater. The researchers chose 1200/1800 as a cut-off score to indicate high-ability because this is the minimum requirement for acceptance into the honors program at University A.

A total of 421 high ability college students across the two universities returned the survey, whereby 153 were from University A and 268 were from University B. $T$-tests showed no significant differences between the participants from the two universities with regard to the mean scores of locus of control, academic self-concept, and academic dishonesty.

Missing data. Missing data in longitudinal social science research is not uncommon (Juster \& Smith, 1997). In particular, college students are responding at lower rates than in previous decades (Dey, 1997). In the current study, a total of 64 cases within the three variables (i.e., locus of control, academic self-concept, and academic dishonesty) were missing substantial portions of the scale data. List-wise deletion was used to remove those 64 cases from the study. The data set from the remaining 357 participants still had some missing data points scattered throughout. Therefore, the expectation maximization (EM) algorithm via the Statistical Package for the Social Sciences (SPSS) 17.0 Missing Values Analysis (MVA) was used to further examine the missing data. The results of the test for missingness revealed the missing data were missing completely at random (MCAR) $(p=.45)$. Multiple data imputation (MI) for data MCAR (Peugh \& Enders, 2004) was used to generate models with imputed values for the missing data. The imputed values were produced using full information maximum likelihood (FIML) estimation (Dempster, Laird, \& Rubin, 1977; Enders \& Bandalos, 2001) by means of the EM algorithm. Using MI to replace missing data retains the sample size, maintains statistical power, and preserves variance in the data set (Peugh \& Enders).

In the final data set, 179 students were in the honors group and 178 students were in the non-honors group. The disaggregate honors and non-honors groups of participants together comprise the aggregate group of participants $(n=357)$. Age, gender, and ethnicity data for the participants is presented in Table 1. The mean age of the participants in this study is approximately 19 years 11 months. There were more female participants than male participants in all groups. In addition, approximately three-fourths of the participants in all groups identify themselves as Caucasian. Standardized test scores were examined by whole group, and by honors membership (see Table 2). 
Rinn, A.N., \& Boazman, J.

Table 2

Descriptive Statistics for ACT/SAT Test Scores

\begin{tabular}{|c|c|c|c|c|c|c|c|c|c|}
\hline & \multicolumn{3}{|c|}{ Whole-Group } & \multicolumn{3}{|c|}{ Honors } & \multicolumn{3}{|c|}{ Non-Honors } \\
\hline & $N$ & $M$ & $S D$ & $N$ & $M$ & $S D$ & $N$ & $M$ & $S D$ \\
\hline ACT & 146 & 30.53 & 2.60 & 68 & 30.44 & 2.64 & 78 & 30.93 & 2.33 \\
\hline SAT (old version) & 159 & 1388.13 & 142.70 & 60 & 1435.70 & 185.90 & 99 & 1359.29 & 98.99 \\
\hline SAT (new version) & 52 & 2028.63 & 155.41 & 51 & 2029.60 & 156.83 & 1 & 1980.00 & \\
\hline
\end{tabular}

\section{Measurement Instruments}

Locus of control. Locus of control was measured using Rotter's Internal-External Locus of Control Scale (I-E Scale; Rotter, 1966). The I-E Scale consists of 23 forced choice items and six filler items, which were designed to make the questionnaire more ambiguous to respondents. The 23 forced choice items measure beliefs about "the nature of the world" and each item is comprised of an internal statement paired with an external statement (Rotter, p. 10). Scores range from 0 (most external) to 23 (most internal). Sample items include, "Many of the unhappy things in people's lives are partly due to bad luck versus People's misfortunes result from the mistakes they make" and "The average citizen can have an influence in government decisions versus This world is run by the few people in power, and there is not much the little guy can do about it." In a meta-analysis of studies using the I-E Scale, Beretvas, Suizzo, Durham, and Yarnell (2008) found an internal consistency mean of .66 and a median of .69. Cronbach alpha for the current administration of the I-E Scale is .74.

Academic self-concept. Academic self-concept was measured using the academic selfconcept subscale of The Self-Description Questionnaire III (SDQ-III; Marsh, 1989). The SDQIII is based on the Shavelson model of self-concept, which supports the notion that self-concept is both multifaceted and hierarchical (Shavelson et al., 1976).

The SDQ-III contains 136 items and measures 13 facets of self-concept (Marsh \& O'Neill, 1984). Each facet is measured by 10 to 12 items, whereby responses range from 1 (definitely false) to 8 (definitely true). Half of the items are negatively worded (Marsh, 1989). The SDQ-III assesses four areas of academic self-concept (math, verbal, academic, and problem solving), eight areas of nonacademic self-concept (physical ability, physical appearance, relations with the same sex, relations with the opposite sex, relations with parents, spiritual values/religion, honesty/trustworthiness, and emotional stability), and general self-concept. Marsh (1989) provides strong psychometric support for the SDQ-III, including scores of reliability, correlations with external criteria, and self-other agreement. Historically, cores of internal consistency range from $\alpha=0.74$ to $\alpha=0.95$ for the subscales of the SDQ-III. Cronbach alpha for the administration of the academic self-concept subscale of the SDQ-III with the present population is 87 .

For the purposes of this study, the general academic subscale of the SDQ-III was used to measure academic self-concept. The meaning of the academic subscale, as defined by Marsh 
(1989), is "I am a good student in most school subjects." The academic subscale contains 10 items including, "I enjoy doing work for most academic subjects" and "I have trouble with most academic subjects" (p. 12). Reliability scores for the academic subscale of the SDQ-III range from 0.86 to 0.92 (Marsh \& Byrne, 1993). See Rinn and Cunningham (2008) for further validity and reliability evidence for the academic self-concept subscale for use with high ability college students. Factor analysis indicates factor loadings range from 0.47 to 0.81 on the academic subscale (Marsh, 1989). Factors correlated with the academic self-concept subscale range from 0.06 (physical ability subscale and opposite sex relationships subscale) to 0.33 (math subscale). Overall, the factor structure of the SDQ-III is consistent with the hypothesized hierarchical model of self-concept originally proposed by Shavelson et al. (1976).

Academic dishonesty. Academic dishonesty was measured using an adaptation of the work by Geddes (2011). Geddes created a questionnaire designed to measure motivations for cheating and cheating behaviors/rates of occurrence that was used to examine the academic dishonesty behaviors of gifted high school students. Geddes created the questionnaire based on a review of the literature and a survey of students' and colleagues' experiences.

The portion of the questionnaire that measures cheating behaviors lists 13 specific behaviors and asks students to identify the number of times they had engaged in that behavior. The answer range for the cheating behaviors portion of the questionnaire is "never" to "more than five times." From the data collected in this scale Geddes (2011) reported the percent of participants who indicated they had engaged in the behavior.

The second portion of the questionnaire used by Geddes (2011) includes a broader range of reasons/motivations for academic dishonesty. This portion of the questionnaire included three categories regarding one's intention to engage in academic dishonesty: academic reasons, nonacademic reasons, and neutralizing attitudes. The questionnaire requires students to consider 31 possible motivations for academic dishonesty and to rate each from "strongly disagree" to "strongly agree" on each item being a motivation for cheating. Geddes then reported the percent of students in agreement for each item.

The current study requires a scale that results in a report of actual incidence of cheating so that the relationships between locus of control, academic self-concept, and academic dishonesty can be examined. By modifying the portion of the questionnaire designed to measure motivation for academic dishonesty used by Geddes (2011), researchers were able to ask students if they had engaged in academic dishonesty and ascertain student motivation for the engagement. Students were asked to provide the rate at which they had engaged in academic dishonesty because of the motivation listed. The rate for the scale is "never" to "five or more times." A rate closer to the zero end of the scale indicates less incidence of academic dishonesty due to the corresponding motivation. Researchers also believed that students might be more willing to respond to reasons for engaging in academically dishonest behaviors than providing information on specific rates and types of academically dishonest behavior.

Of the 31 items used by Geddes (2011), 24 were chosen. Researchers chose the items most relevant for a university sample, combined some of the items, and reworded items so that they were specific to a university sample. The result was a 20 -item scale that asked students to rate the number of times they engaged in academic dishonesty for each motivation (see Appendix A). Factor analysis was conducted to examine the factor structure of the revised scale. Where Geddes (2011) used the questions on motivation for cheating as a single questionnaire that asked questions related to academic, non-academic, and neutralizing reasons for cheating, our data revealed a two factor structure for the newly adapted Motivation for Academic 
Dishonesty scale used in the current study. Details for the factor analysis are presented in the results section.

\section{Procedure}

An e-mail was sent to students at both universities that invited them to participate in an online research study regarding college student experiences. The participants who responded resulted in a convenience sample. Participants were asked to electronically sign an informed consent document and then complete a series of online questionnaires. When coding the participants in the data file, honors participants were coded as 1 and non-honors participants were coded as 2. Statistical Package for the Social Sciences (SPSS) was used to examine the variables and the interaction of locus of control and academic dishonesty.

\section{Results}

To explore the relationship between locus of control (LOC) and academic dishonesty (AD) as moderated by academic self-concept (ASC), researchers modified a portion of the Geddes (2011) questionnaire designed to measure academic dishonesty and conducted a principal factor analysis to examine the construction of the newly developed Motivation for Academic Dishonesty scale. Once the factor analysis of the Motivation for Academic Dishonesty scale was complete, a multiple regression analysis was conducted with academic dishonesty as the dependent variable, locus of control and academic self-concept as the independent variables, and LOC x ASC as a moderator variable. In addition, the relationship between locus of control and academic dishonesty, as moderated by academic self-concept was examined by aggregate and disaggregate groupings (honors vs. non-honors).

\section{Factor Analysis of the Motivation for Academic Dishonesty Scale}

Geddes (2011) did not report a factor analysis on her questionnaire designed to measure academic dishonesty among high ability students. However, Geddes grouped the items in the portion of the questionnaire that was designed to measure motivations for cheating into three categories: academic reasons, non-academic reasons, and neutralizing attitudes. In the current study, the researchers chose 24 items from the Geddes questionnaire that were most relevant for a university sample. Once the questionnaire items were chosen, modifications to those items were made to create a 20 -item scale relevant for a university population. Factor analysis was then conducted to determine if the factor structure of the modified scale was similar to the three divisions Geddes used.

The initial step in the factor analysis for the 20-item Motivation for Academic Dishonesty scale was the consideration of factorability. Four criteria were used to determine the factorability of the correlation of scale items for the current study: item correlation, Kaiser-Meyer-Olkin measure of sampling adequacy, Bartlett's test of sphericity, and communality values. First, item correlation greater than 0.3 with at least one other item was achieved indicating reasonable factorability. Next, the Kaiser-Meyer-Olkin measure of sampling adequacy was 0.91, well above the recommended value of 0.5 (Tabachnick \& Fidell, 2007). The Bartlett's test of sphericity was significant $\left(\chi^{2}[190]=5677.50, p<.01\right)$. Lastly, all communality values, except one, were above 0.3 (see Table 3 ) indicating that the items shared common variance with other items. With 
Rinn, A.N., \& Boazman, J.

Table 3

Communalities - Individual Motivation for Academic Dishonesty Scale

Scale Items

Communalities

\begin{tabular}{|c|c|c|c|c|}
\hline & $\begin{array}{r}20 \\
\text { Initial } \\
\end{array}$ & $\begin{array}{l}\text { Item } \\
\text { Extracted }\end{array}$ & $\begin{array}{r}17 \\
\text { Initial } \\
\end{array}$ & $\begin{array}{l}\text { Item } \\
\text { Extracted }\end{array}$ \\
\hline Unfair teacher & .83 & .83 & .80 & .81 \\
\hline Teacher did not adequately explain material & .73 & .78 & .76 & .76 \\
\hline School workload too heavy & .70 & .68 & .64 & .63 \\
\hline Teachers' demands are unreasonable & .71 & .69 & .69 & .68 \\
\hline Overly harsh grading & .74 & .73 & .67 & .68 \\
\hline Illness prevents adequate preparation & .58 & .57 & .43 & .44 \\
\hline Too many tests on one day & .74 & .73 & .71 & .71 \\
\hline Easier than studying & .72 & .66 & .62 & .60 \\
\hline The material is not important & 67 & .66 & .55 & .53 \\
\hline Others' cheating puts you at a disadvantage & .49 & .22 & .22 & .21 \\
\hline Others cheat & 66 & .53 & & \\
\hline Driven by high GPA & .51 & .32 & & \\
\hline $\begin{array}{l}\text { More competitive for graduate school or professional school } \\
\text { admission }\end{array}$ & .73 & .72 & .72 & .74 \\
\hline Feeling of pressure from parents & .70 & .70 & .70 & .72 \\
\hline To maintain eligibility for a scholarship & .69 & .65 & .59 & .56 \\
\hline Need to excel at any cost & .63 & .61 & .59 & .57 \\
\hline To maintain eligibility for athletic qualification & .72 & .68 & .54 & .57 \\
\hline Didn't have the ability to do well in the class without cheating & .69 & .60 & .47 & .47 \\
\hline Job leaves no time for studying & .70 & .69 & .64 & .65 \\
\hline Lack of effort/ did not study or attend class & .63 & & .49 & \\
\hline
\end{tabular}

consideration of these indicators, it was determined that the set of scale items were factorable. The factor analysis was continued using all 20 items.

Principal factor analysis, with direct oblimin rotation, and maximum likelihood extraction, was conducted on the Motivation for Academic Dishonesty scale, for the aggregate group of 357 high ability college students. A parallel analysis (Horn, 1965), also referred to as an eigenvalue Monte Carlo simulation, was conducted to determine the number of factors to extract in the analysis. A raw data permutation approach to data generation for the Monte Carlo simulation was used. A comparison of the permutated data at the 95th percentile for each component, to the raw data for each component, showed the 3rd factor permutated data to be greater than the raw data. This result indicates the permutated data ceased to be significant at the 
third component, revealing a two factor structure for the Motivation for Academic Dishonesty scale (see Table 4). Once the number of factors to extract had been determined for the aggregate

Table 4

Eigenvalue Monte Carlo Simulation

\begin{tabular}{|c|c|c|}
\hline \multicolumn{3}{|c|}{ Composite Group } \\
\hline Root & Raw Data & $\begin{array}{c}\text { Raw Data Permutation } \\
95^{\text {th }} \text { percentile }\end{array}$ \\
\hline 1 & 9.35 & 1.53 \\
\hline 2 & 1.72 & 1.39 \\
\hline 3 & .94 & 1.30 \\
\hline \multicolumn{3}{|c|}{ Honors } \\
\hline 1 & 10.67 & 1.91 \\
\hline 2 & 2.59 & 1.63 \\
\hline 3 & 1.11 & 1.47 \\
\hline \multicolumn{3}{|c|}{ Non-Honors } \\
\hline 1 & 8.61 & 1.76 \\
\hline 2 & 1.70 & 1.57 \\
\hline 3 & 1.03 & 1.44 \\
\hline
\end{tabular}

group, the same Monte Carlo simulation was conducted for the disaggregate honors and nonhonors groups to determine if the number of factors was the same in the disaggregate groups. When the permutated data, at the 95th percentile, were compared to the raw data, the permutated data ceased being significant after the second component indicating a two factor structure for the disaggregate groups as well (see Table 4).

Once the factorability and the number of factors to extract were determined, the factor analysis continued with an examination of factor loadings (see Table 5). The two factors accounted for $58.28 \%$ of the total variance. However, three items in the Motivation for Academic Dishonesty scale had low initial loadings and cross loaded on the second factor. Those three items, "others cheat," "driven by high GPA," and "lack of effort/did not study or attend class," were removed from the scale and a second factor analysis was conducted with the remaining 17 items.

In the 17-item Motivation for Academic Dishonesty scale, the Kaiser-Meyer-Olkin measure of sampling adequacy changed to 0.92, the Bartlett's test of sphericity was significant $\left(\chi^{2}[136]=4829.77, p<.01\right)$ and all but one communality values were above 0.3 (see Table 3 ). In the 17 item scale, the overall variance accounted for rose to $60.73 \%$, with the first factor explaining $52.78 \%$ of the total variance and the second factor explaining an additional $7.95 \%$ of the total variance. Clear loadings were established in the 17-item scale (see Table 5). 
The two factor structure determined in this analysis is different than the three groupings that Geddes (2011) created. In the current study, the two factors are interpreted as internal and external forces that create motivation to engage in academic dishonesty. Internal consistency for each factor was examined using Crohbach's alpha. Alpha values for the two factors were good, with factor 1 (imposition of external influences, such as overly harsh grading and poor instruction) alpha being .92, and alpha for factor 2 (imposition of internal influences, such as perceived ability level and drive to succeed) being .86 .

Table 5

Factor Loadings - Individual Motivation for Academic Dishonesty Scale

\begin{tabular}{|c|c|c|c|c|}
\hline \multirow[t]{3}{*}{ Scale Items } & \multicolumn{4}{|c|}{ Factor Loadings } \\
\hline & \multicolumn{2}{|c|}{20 Item } & \multicolumn{2}{|c|}{17 Item } \\
\hline & External & Internal & External & Internal \\
\hline Unfair teacher & .94 & & .94 & \\
\hline Teacher did not adequately explain material & .94 & & .93 & \\
\hline School workload too heavy & .82 & & .81 & \\
\hline Teachers' demands are unreasonable & .80 & & .79 & \\
\hline Overly harsh grading & .76 & & .74 & \\
\hline Illness prevents adequate preparation & 69 & & 69 & \\
\hline Too many tests on one day & 67 & & .67 & \\
\hline Easier than studying & .60 & & .59 & \\
\hline The material is not important & .58 & & .57 & \\
\hline Others' cheating puts you at a disadvantage & .50 & & .49 & \\
\hline Others cheat why shouldn't I & .48 & .31 & & \\
\hline Driven by high GPA & .33 & .29 & & \\
\hline $\begin{array}{l}\text { More competitive for graduate school or } \\
\text { professional school admission }\end{array}$ & & .90 & & .91 \\
\hline Feeling of pressure from parents & & .87 & & .88 \\
\hline To maintain eligibility for a scholarship & & .80 & & .77 \\
\hline Need to excel at any cost & & .75 & & .72 \\
\hline $\begin{array}{l}\text { To maintain eligibility for athletic } \\
\text { qualification }\end{array}$ & & .66 & & .69 \\
\hline $\begin{array}{l}\text { Didn't have the ability to do well in the } \\
\text { class without cheating }\end{array}$ & & .54 & & .54 \\
\hline Job leaves no time for studying & & .52 & & .53 \\
\hline Lack of effort/ did not study or attend class & .37 & .39 & & \\
\hline
\end{tabular}




\section{Moderation Analysis}

The moderation analysis in the current study used the newly established 17-item Motivation for Academic Dishonesty scale. Descriptive statistics for the variables of interest, locus of control (LOC), Academic Self-Concept (ASC), and Motivation for Academic Dishonesty (MAD), are presented in Table 6.

Correlation. The first step in the moderation analysis is to determine if the independent variables (locus of control and academic self-concept) are correlated with the dependent variable (academic dishonesty, 17-item scale). A Pearson product moment correlation (Pearson, 1895) was used to determine correlated variables for the aggregate group and each disaggregate group (see Table 7). In the current study, locus of control is not statistically significantly correlated with academic dishonesty in the whole-group, nor in the honors group. Without correlation between the independent and dependent variables, further moderation analysis was not able to be conducted with these two groups. There was a small, yet significant, correlation between locus of control and academic dishonesty $(r[176]=-0.21, p<.001)$, as well as between academic selfconcept and academic dishonesty $(r[176]=-0.29, p<.001)$ for the non-honors group and further analysis was conducted for the non-honors group.

Regression. Without correlation of locus of control with academic dishonesty in the composite group or the honors group, regression moderation analysis was not completed for those groups. Correlation results in the non-honors group showed a small yet significant correlation between locus of control and the external motivation for academic dishonesty factor. A multiple regression using the enter method was conducted between external motivation for academic dishonesty factor as the dependent variable, and locus of control (LOC), academic selfconcept (ASC), and the moderator variable (LOC X ASC) as the independent variables. Table 8 presents the results from the regression analysis. The results for the overall model for this regression were statistically significant, $F(1,175)=6.05, p=.001$, with a small effect $R^{2}=.095$. In further examination of the multiple regression model, none of the independent variables, locus of control $(p=.57)$, academic self-concept $(p=.26)$, or interaction of locus of control with academic self-concept $(p=.86)$, made a significant individual contribution to the $9.5 \%$ variance accounted for by the overall regression model. The non-significance of the interaction variable

(locus of control with academic self-concept) indicates there is no moderation effect between locus of control and academic self-concept when regressed on external factors related to motivation for academic dishonesty in this study.

\section{Discussion}

The current study evaluated a measure of academic dishonesty and examined high ability college students' loci of control and its effect on behaviors of academic dishonesty, as moderated by academic self-concept. In addition, high-ability students in an honors program were compared to high-ability students who were not enrolled in an honors program.

The Motivation for Academic Dishonesty scale developed for the current study is a modification of the Motivation for Cheating scale created by Geddes (2011). The initial principal components analysis indicated that three items had low initial loadings and cross loaded on both factors. Once those three items were removed, the rerun of the principal components analysis revealed a clear two factor structure for the 17-item scale. This result is different than the three 
Rinn, A.N., \& Boazman, J.

Table 6

Descriptive Statistics for Variables of Interest

\begin{tabular}{|c|c|c|c|c|c|c|c|c|c|c|c|c|c|}
\hline & & \multicolumn{4}{|c|}{ Whole-Group $(\mathrm{n}=357)$} & \multicolumn{4}{|c|}{ Honors $(\mathrm{n}=179)$} & \multicolumn{4}{|c|}{ Non-honors $(\mathrm{n}=178)$} \\
\hline & & $M$ & $S D$ & Skew & Kurt & $M$ & $S D$ & Skew & Kurt & $M$ & $S D$ & Skew & Kurt \\
\hline $\begin{array}{l}\text { Locus of } \\
\text { Control }\end{array}$ & $23^{*}$ & 12.50 & 4.22 & -.19 & -.46 & 12.08 & 4.08 & -.17 & -.62 & 12.92 & 4.33 & -.24 & -.32 \\
\hline $\begin{array}{l}\text { Acad. } \\
\text { Self- } \\
\text { Concept }\end{array}$ & $8^{*}$ & 6.41 & 0.89 & -.79 & .89 & 6.54 & 0.78 & -.72 & 1.04 & 6.28 & .98 & -.71 & .50 \\
\hline Composite & & & & 5.66 & 39.42 & & & 6.61 & 47.68 & & & 5.22 & 38.61 \\
\hline Academic & $85^{*}$ & 19.89 & 8.65 & & & 19.20 & 8.34 & & & 21.79 & 9.46 & & \\
\hline $\begin{array}{l}\text { Dishonesty } \\
\text { (17) }\end{array}$ & $5 *$ & $1.17 * *$ & 0.52 & & & $1.13^{* *}$ & 0.49 & & & $2.18^{* *}$ & 0.56 & & \\
\hline $\begin{array}{l}\text { External } \\
\text { (10) }\end{array}$ & $\begin{array}{r}50^{*} \\
5^{*}\end{array}$ & $\begin{array}{l}12.21 \\
1.22 * *\end{array}$ & $\begin{array}{l}6.20 \\
0.62\end{array}$ & 4.75 & 26.05 & $\begin{array}{l}11.69 \\
1.17 * *\end{array}$ & $\begin{array}{r}5.85 \\
.59\end{array}$ & 5.80 & 35.58 & $\begin{array}{l}13.94 \\
1.39 * *\end{array}$ & $\begin{array}{l}7.05 \\
0.71\end{array}$ & 3.99 & 20.28 \\
\hline $\begin{array}{l}\text { Internal } \\
\text { (7) }\end{array}$ & $\begin{array}{c}35^{*} \\
5^{*}\end{array}$ & $\begin{array}{l}7.68 \\
1.10 * *\end{array}$ & $\begin{array}{l}3.08 \\
0.44\end{array}$ & 8.69 & 87.21 & $\begin{array}{l}7.51 \\
1.07 * *\end{array}$ & $\begin{array}{l}3.12 \\
0.45\end{array}$ & 9.55 & 96.84 & $\begin{array}{l}7.85 \\
1.12^{* *}\end{array}$ & $\begin{array}{l}3.04 \\
0.43\end{array}$ & 7.94 & 80.74 \\
\hline
\end{tabular}

Note: $*$ possible total score, $* *$ mean rate of academic dishonesty $(0=$ never, $5=5$ or more times $)$

category structure of the questionnaire developed by Geddes. Researchers in the current study interpreted the two factors as internal (e.g., perceived ability) and external (e.g., teacher's fault) forces that influence academic dishonesty.

Moderation analysis was not conducted with the aggregate group, nor with the honors group, because locus of control and academic dishonesty were not correlated in those groups. Correlation results in the non-honors group, though, showed a small yet significant correlation between locus of control and the external motivation for academic dishonesty factor. However, locus of control did not significantly contribute to the regression model. That locus of control did not predict academic dishonesty is not in line with previous research in this area, which has shown that an external locus of control is related to an increase in academic dishonesty (Gallagher, 2010; Karabenick \& Srull, 1978; Lefcourt, 1982; Pino \& Smith, 2003). This previous research was conducted with average ability students, though, and cannot be generalized to gifted students. Future research should continue to explore the loci of control of gifted students, in particular, as very little is known about the impact of loci of control on academic outcomes among gifted students.

The correlation between academic self-concept and academic dishonesty in both the honors and the non-honors groups supports previous research that suggests negative or lowered beliefs about one's academic abilities is related to an increase in academically dishonest behavior (Murdock \& Anderman, 2006). Indeed, post hoc analyses show lowered academic self-concept is a predictor of academic dishonesty for non-honors $(F[2,175]=10.38, p=.006$; see Table 9) and honors students $(F[1,177]=6.06 ; p=0.02$; see Table 10$)$. Future research should examine other factors that influence academic self-concept among high ability college students in order to more clearly recognize trends regarding precursors to academic dishonesty.

Journal of the Scholarship of Teaching and Learning, Vol. 14, No. 4, October 2014. 
Rinn, A.N., \& Boazman, J.

Table 7

Correlation Matrix between Variables by Group

\begin{tabular}{|c|c|c|c|c|c|c|}
\hline \multicolumn{7}{|c|}{ Composite } \\
\hline & & 1 & 2 & 3 & 4 & 5 \\
\hline 1 & Academic & & & & & \\
\hline & $\begin{array}{l}\text { Dishonesty } \\
\text { (composite) }\end{array}$ & 1.00 & & & & \\
\hline 2 & Academic & & & & & \\
\hline & $\begin{array}{l}\text { Dishonesty (internal } \\
\text { motivation) }\end{array}$ & $0.86^{* * *}$ & 1.00 & & & \\
\hline 3 & Academic & & & & & \\
\hline & $\begin{array}{l}\text { Dishonesty (external } \\
\text { motivation) }\end{array}$ & $0.97 * *$ & $0.70 * *$ & 1.00 & & \\
\hline 4 & $\begin{array}{l}\text { Academic } \\
\text { Self-Concept }\end{array}$ & $-0.26 * *$ & $-0.24 *$ & $-0.24 * *$ & 1.00 & \\
\hline 5 & Locus of Control & -0.05 & -0.07 & -0.07 & $0.17 *$ & 1.00 \\
\hline & & & Honors & & & \\
\hline 1 & $\begin{array}{l}\text { Academic } \\
\text { Dishonesty } \\
\text { (composite) }\end{array}$ & 1.00 & & & & \\
\hline 2 & Academic & & & & & \\
\hline & $\begin{array}{l}\text { Dishonesty (internal } \\
\text { motivation) }\end{array}$ & $0.85^{* *}$ & 1.00 & & & \\
\hline 3 & $\begin{array}{l}\text { Academic } \\
\text { Dishonesty (external } \\
\text { motivation) }\end{array}$ & $0.96^{* *}$ & $0.70^{* *}$ & 1.00 & & \\
\hline 4 & $\begin{array}{l}\text { Academic } \\
\text { Self-Concept }\end{array}$ & $-0.18^{* *}$ & -0.13 & $-0.19 * *$ & 1.00 & \\
\hline 5 & Locus of Control & 0.11 & 0.11 & 0.09 & 0.13 & 1.00 \\
\hline & & & Jon-Honor & & & \\
\hline 1 & $\begin{array}{l}\text { Academic } \\
\text { Dishonesty } \\
\text { (composite) }\end{array}$ & 1.00 & & & & \\
\hline 2 & $\begin{array}{l}\text { Academic } \\
\text { Dishonesty (internal } \\
\text { motivation) }\end{array}$ & $0.85 * *$ & 1.00 & & & \\
\hline 3 & $\begin{array}{l}\text { Academic } \\
\text { Dishonesty (external } \\
\text { motivation) }\end{array}$ & $0.97 * *$ & $0.71 * *$ & 1.00 & & \\
\hline 4 & $\begin{array}{l}\text { Academic } \\
\text { Self-Concept }\end{array}$ & $-0.29 * *$ & $-0.33^{* *}$ & $-.25 * *$ & 1.00 & \\
\hline 5 & Locus of Control & $-0.21 * *$ & -0.11 & $-.23 * *$ & $0.23^{*}$ & 1.00 \\
\hline
\end{tabular}

Journal of the Scholarship of Teaching and Learning, Vol. 14, No. 4, October 2014. 
Table 8

Regression External Motivation for Academic Dishonesty - Non-Honors

\begin{tabular}{|c|c|c|c|c|c|}
\hline \multirow{2}{*}{ Variable } & \multirow{2}{*}{$b$} & \multicolumn{2}{|c|}{$95 \% \mathrm{CI}$ of $b$} & \multirow{2}{*}{$\beta$} & \multirow{2}{*}{$p$} \\
\hline & & Lower & Upper & & \\
\hline Locus of Control (LOC) & -1.76 & -2.01 & 1.12 & -0.27 & 0.57 \\
\hline Academic Self-Concept (ASC) & -0.45 & -4.85 & 1.32 & -0.24 & 0.26 \\
\hline Interaction (LOC X ASC) & 0.02 & -0.22 & 0.26 & 0.10 & 0.89 \\
\hline$R$ & 0.308 & & & & \\
\hline$R^{2}$ & 0.095 & & & & \\
\hline$F$ & 6.059 & & & & \\
\hline
\end{tabular}

Table 9

Multiple Regression External Motivation for Academic Dishonesty - Non-Honors

\begin{tabular}{|c|c|c|c|c|c|c|}
\hline \multirow{2}{*}{ Variable } & \multirow{2}{*}{$b$} & \multicolumn{2}{|c|}{$95 \%$ CI of $b$} & \multirow{2}{*}{$\beta$} & \multirow{2}{*}{$p$} & \multirow{2}{*}{$r_{s}^{2}$} \\
\hline & & Lower & Upper & & & \\
\hline Locus of Control (LOC) & -0.30 & -0.54 & -0.07 & -0.19 & 0.01 & 0.74 \\
\hline Academic Self-Concept (ASC) & -1.50 & -2.56 & -0.43 & -0.21 & 0.01 & 0.81 \\
\hline$R$ & 0.31 & & & & & \\
\hline$R^{2}$ & 0.09 & & & & & \\
\hline$F$ & 9.12 & & & & & \\
\hline
\end{tabular}

Table 10

Regression, External Motivation for Academic Dishonesty - Honors

\begin{tabular}{lrrrrrr}
\hline \multirow{2}{*}{ Variable } & & \multicolumn{2}{c}{$95 \%$ CI of $b$} & & \multirow{2}{*}{$\beta$} \\
\cline { 3 - 4 } & & Lower & Upper & & \\
\hline Academic Self-Concept (ASC) & -1.94 & -3.50 & -0.39 & & -.18 & 0.02 \\
$R$ & 0.18 & & & & \\
$R^{2}$ & 0.03 & & & & \\
$F$ & 6.06 & & & & \\
\hline
\end{tabular}

\section{Limitations and Directions for Future Research}

The current sample was obtained at only two institutions and by using a convenience sampling method, both of which naturally limit the generalizability of the findings. Future research should replicate the current study across multiple institutions and multiple groups of high ability college students, and also with the use of an average ability control group. The following limitations should be understood with the lack of generalizability of the current study in mind. 
The designation of "high ability" students in this study was based solely on students' SAT/ACT scores. While SAT/ACT scores are almost always used in admissions decisions to higher education and to honors programs within higher education (Digby, 1999; Pascarella \& Terenzini, 1991; 2005), a standardized test score is not necessarily indicative of one's intellectual capacity (Bridgeman, 2005). While we have avoided using the term "gifted" in reference to the current sample, and focused on "high ability" students instead, the problems in using SAT/ACT scores as a measure of ability is still noteworthy. However, the lack of a stronger indicator makes using SAT/ACT scores the most appropriate choice at this point in time.

Although grade point average data were not collected in this study, future research should examine the role of grade point average or academic achievement in the relationship between locus of control, academic self-concept, and academic dishonesty. Locus of control and academic self-concept likely affect academic achievement, and academic achievement and academic dishonesty are typically negatively related (Crown \& Spiller, 1998; Haines et al., 1986; McCabe \& Trevino, 1997; Singhal, 1982; Whitley, 1998). Because high ability students are often high achievers, the role of academic achievement could be particularly salient among this population.

Rates of academic dishonesty were self-reported in the current study. Miller, Shoptaugh, and Parkerson (2008) found that using a volunteer sampling procedure (such as was used in the current study) leads to an underreporting of cheating behaviors. This could happen for a variety of reasons: 1) those who cheat regularly may avoid participating in a research project that blatantly asks about academically dishonest behaviors (Miller et al., 2008); 2) concerns about anonymity (Scheers \& Dayton, 1987); or 3) gender of the participant (McCabe \& Trevino, 1997). Thus, the potential underreporting of academically dishonest behavior in the current study could significantly impact the findings, such that true reporting of academically dishonest behavior may impact the model tested in this study. Further, academic dishonesty could be measured differently, such that actual rates of academic dishonesty are measured rather than motivation for academic dishonesty.

Future research should examine locus of control, academic self-concept, and academic dishonesty in a domain-specific manner. Indeed, research indicates ability attributions are domain-specific for gifted individuals, whereas effort attributions are generalizable across academic domains ( $\mathrm{Li} \&$ Adamson, 1995). Academic self-concept is also domain-specific, particularly as individuals get older (Marsh, 1990). Thus, it follows that academic dishonesty may only occur in domain-specific areas.

Finally, future research should examine other mediators and moderators in the relationship between locus of control, academic self-concept, and academic dishonesty. For example, among high ability students, such issues as intrinsic respect for the teacher and the coursework, motivation, or goal orientation (wanting to master the material versus simply pass an exam or course) might be influential in one's decision to engage in academically dishonest behavior.

\section{Conclusion}

Results from the current study suggest previous relationships found between locus of control and academic dishonesty among average ability samples may differ among high ability college students. While academic self-concept remains an important variable in the prediction of academic dishonesty, it does not moderate the relationship between locus of control and 
academic dishonesty in the current sample. Other achievement-related beliefs need to be explored as precursors to academic self-concept, and as predictors of academic dishonesty, among high ability college students.

\section{Appendix A}

\section{Feelings about Academic Cheating}

Instructions: During the previous academic year, did you cheat on a homework assignment, project, research paper, quiz, exam, or other academic assignment for any of the following reasons? Rate on a 0 (never) to 5 (five or more times) scale.

1) Driven by high GPA

2) To maintain eligibility for a scholarship

3) More competitive for graduate school or professional school admission

4) Too many tests on one day

5) School workload too heavy

6) Easier than studying

7) Others' cheating puts you at a disadvantage

8) Teachers' demands are unreasonable

9) The material is not important

10) Need to excel at any cost

11) Teacher did not adequately explain material

12) Didn't have the ability to do well in the class without cheating

13) Pressure from parents

14) Job leaves no time for studying

15) Illness prevents adequate preparation

16) To maintain eligibility for athletic qualification

17) Unfair teacher

18) Overly harsh grading

19) Lack of effort/ did not study or attend class

20) Others cheat

\section{References}

Abilock, D. (2009). Guiding the gifted to honest work. Knowledge Quest, 37, 12-15.

Ablard, K. E. (1997). Self-perceptions and needs as a function of type of academic ability and gender. Roeper Review, 20, 110-115. doi: 10.1080/02783199709553870

Alarape, A. I., \& Onakoya, A. Y. (2003). Correlates of examination cheating behavior among university students. IFE Psychologia: An International Journal, 11, 71-79.

Anazonwu, C. O. (1995). Locus of control, academic self-concept, and attribution of responsibility for performance in statistics. Psychological Reports, 77, 367-370. doi: 10.2466/pr0.1995.77.2.367 
Antion, D. L., \& Michael, W. B. (1983). Short-term predictive validity of demographic, affective, personal, and cognitive variables in relation to two criterion measures of cheating behaviors. Educational and Psychological Measurement, 43, 467-482. doi:

$10.1177 / 001316448304300216$

Arvidson, C. J. (2004). The anatomy of academic dishonesty: Cognitive development, selfconcept, neutralization techniques, and attitudes towards cheating (Unpublished doctoral dissertation). University of North Texas, Denton, TX.

Assouline, S. G., Colangelo, H., Ihrig, D., \& Forstadt, L. (2006). Attributional choices for academic success and failure by intellectually gifted students. Gifted Child Quarterly, 50, 283294. doi: 10.1177/001698620605000402

Benson, H., Kornhaber, A., Kornhaber, C., Lechanu, M., Zuttermeister, P., Myers, P., \& Friedman, R. (1994). Increases in positive psychological characteristics with a new relaxationresponse curriculum in high school students. Journal of Research and Development in Education, 27, 226-231.

Beretvas, S. N., Suizzo, M., Durham, J. A., \& Yarnell, L. M. (2008). A reliability generalization study of scores on Rotter's and Nowicki-Strickland's locus of control scales. Educational and Psychological Measurement, 68, 97-119. doi: 0.1177/0013164407301529

Bridgeman, B. (2005). Unbelievable results when predicting IQ from SAT scores: A commentary on Frey and Detterman (2004). Psychological Science, 16, 745-746. doi: 10.1111/j.1467-9280.2005.01606.x

Carden, R., Bryant, C., \& Moss, R. (2004). Locus of control, test anxiety, academic procrastination, and achievement among college students. Psychological Reports, 95, 581-582. doi: $10.2466 / p r 0.95 .2 .581-582$

Carton, J. S., \& Nowicki, Jr., S. (1994). Antecedents of individual differences in locus of control of reinforcement: A critical review. Genetic, Social and General Psychology Monographs, 120, 33-82.

Center for Academic Integrity. (2007). Facts about plagiarism. Retrieved from http://www.plagiarism.org/plag_facts.html

Chan, L. K. S. (1996). Motivational orientations and metacognitive abilities of intellectually gifted students. Gifted Child Quarterly, 40, 184-194. doi: 10.1177/001698629604000403

Colangelo, N., Kelly, K. R., \& Schrepfer, R. M. (1987). A comparison of gifted, general, and special learning needs students on academic and social self-concept. Journal of Counseling and Development, 66, 73-77. doi: 10.1002/j.1556-6676.1987.tb00802.x

Coleman, N., \& Mahaffey, T. (2000). Business student ethics: Selected predictors of attitudes toward cheating. Teaching Business Ethics, 4, 121-136. doi: 10.1023/A:1009855128668 
Collier, R. G., Jacobsen, M. G., \& Stahl, S. A. (1987). Locus of control measurements for gifted and nongifted children. Roeper Review, 9, 196-200. doi: 10.1023/A:1009855128668

Crandall, V. C., \& Crandall, B. W. (1983). Maternal and childhood behaviors as antecedents of internal-external control perceptions in young adulthood. In H. M. Lefcourt (Ed.), Research with the locus of control construct. Vol. 2. Developments and social problems (pp. 53-103). San Diego, CA: Academic Press.

Crown, D. F., \& Spiller, M. S. (1998). Learning from the literature on collegiate cheating: A review of empirical research. Journal of Business Ethics, 17, 229-246. doi: 10.1023/A:1017903001888

Dempster, A. P., Laird, N. M., \& Rubin, D. B. (1977). Maximum likelihood from incomplete data via the EM algorithm (with discussion). Journal of the Royal Statistical Society, 39, 1-38.

Dey, E. (1997). Working with low survey response rates: The efficacy of weighting adjustments. Research in Higher Education, 38, 215-227. doi: 10.1023/A:1024985704202

Digby, J. (1999). Peterson's honors programs: The official guide of the National Collegiate Honors Council ( $2^{\text {nd }}$ ed.). Princeton, NJ: Peterson's.

Downs, W. R., \& Rose, S. R. (1991). The relationship of adolescent peer groups to the incidence of psychosocial problems. Adolescence, 26, 473-492.

Enders, C. K., \& Bandalos, D. L. (2001). The relative performance of full information maximum likelihood estimation for missing data in structural equation models. Structural Equation Modeling: A Multidisciplinary Journal, 8, 430-457. doi: 10.1207/S15328007SEM0803_5

Fimian, M. J., \& Cross, A. H. (1986). Stress and burnout among preadolescent and early adolescent gifted students: A preliminary investigation. Journal of Early Adolescence, 6, 247267. doi: $10.1177 / 0272431686063004$

Findley, M. J., \& Cooper, H. M. (1983). Locus of control and academic achievement: A literature review. Journal of Personality and Social Psychology, 44, 419-427. doi: 10.1037/00223514.44.2.419

Gadzella, B. M., Williamson, J. D., \& Ginther, D. W. (1985). Correlations of self-concept with locus of control and academic performance. Perceptual and Motor Skills, 61, 639-645. doi: 10.2466/pms.1985.61.2.639

Gallagher, J. A. (2010). Academic integrity and personality (Unpublished Master's thesis). California State University: Long Beach, CA.

Gardner, W. M., \& Melvin, K. B. (1988). A scale for measuring attitude toward cheating. Bulletin of the Psychonomic Society, 26, 429-432. doi: 10.3758/BF03334905 
Geddes, K. A. (2011). Academic dishonesty among gifted and high-achieving students. Gifted Child Today, 34, 50-56.

Haines, V. J., Diekhoff, G. M., LaBeff, E. E., \& Clark, R. E. (1986). Immaturity, lack of commitment, and the neutralizing attitude. Research in Higher Education, 25, 342-354. doi: 10.1007/BF00992130

Harty, H., Adkins, D., \& Hungate, E. (1984). Exploring self-concept and locus of control of students in two recognized approaches to elementary school gifted education. Roeper Review, 7 , 88-91. doi: 10.1080/02783198409552857

Heider, F. (1958). The psychology of interpersonal relationships. New York, NY: Wiley. doi: $10.1037 / 10628-000$

Heller, K. A., \& Ziegler, A. (1996). Gender differences in mathematics and the sciences: Can attributional retraining improve the performance of gifted females? Gifted Child Quarterly, 40, 200-210. doi: 10.1177/001698629604000405

Horn, J. L. (1965). A rationale and test for the number of factors in factor analysis. Psychometrika, 30, 179-185. doi: 10.1007/BF02289447

Jones, D. L. R. (2011). Academic dishonesty: Are more students cheating? Business Communication Quarterly, 74, 141-150. doi: 10.1177/1080569911404059

Juster, F. T., \& Smith, J. P. (1997). Improving the quality of economic data: Lessons from the HRS and AHEAD. Journal of the American Statistical Association, 92, 1268-1278. doi: 10.1080/01621459.1997.10473648

Kanoy, R. C., Johnson, B. W., \& Kanoy, K. W. (1980). Locus of control and self-concept in achieving and underachieving bright elementary students. Psychology in the Schools, 17, 359399. doi: 10.1002/1520-6807(198007)17:3<395::AID-PITS2310170320>3.0.CO;2-N

Karabenick, S. A., \& Srull, T. K. (1978). Effects of personality and situational variation in locus of control on cheating: Determinants of the "congruence effect." Journal of Personality, 46, 7295. doi: 10.1111/j.1467-6494.1978.tb00603.x

Karnes, F. A., \& D’Ilio, V. R. (1991). Locus of control in rural southern elementary gifted students. Psychological Reports, 69, 927-928. doi: 10.2466/pr0.1991.69.3.927

Keith, T. Z., Pottebaum, S. M., \& Eberhardt, S. (1986). Effects of self-concept and locus of control on academic achievement: A large-sample path analysis. Journal of Psychoeducational Assessment, 4, 61-72. doi: 10.1177/073428298600400107

Kirkpatrick, M. A., Stant, K., \& Downes, S., \& Gaither, L. (2008). Perceived locus of control and academic performance: Broadening the construct's applicability. Journal of College Student Development, 49, 486-496. doi: 10.1353/csd.0.0032 
Knight, B. A. (1995). The influence of locus of control on gifted and talented students. Gifted Education International, 11, 31-33.

Kormanik, M. B., \& Rocco, T. S. (2009). Internal versus external control of reinforcement: A review of the locus of control construct. Human Resource Development Review, 8, 463-483. doi: $10.1177 / 1534484309342080$

LaBeff, E. E., Clark, R. E., Haines, V. J., Diekhoff, G. M. (1990). Situational ethics and college cheating. Sociological Inquiry, 60, 190-198. doi: 10.1111/j.1475-682X.1990.tb00138.x

Laffoon, K. S., Jenkins-Friedman, R., \& Tollefson, N. (1989). Casual attributions of underachieving gifted, achieving gifted, and nongifted students. Journal for the Education of the Gifted, 13, 4-21.

Lefcourt, H. M. (1966). Internal versus external control of reinforcement: A review. Psychological Bulletin, 65, 206-220. doi: 10.1037/h0023116

Lefcourt, H. M. (1982). Locus of control: Current trends in theory and research (2 $\left.{ }^{\text {nd }} e d.\right)$. Hillsdale, NJ: Erlbaum.

Lent, R. W., Brown, S. D., \& Gore, P. A. (1997). Discriminant and predictive validity of academic self-concept, academic self-efficacy, and mathematics-specific self-efficacy. Journal of Counseling Psychology, 44, 307-315. doi: 10.1037/0022-0167.44.3.307

Li, A. K. F., \& Adamson, G. (1995). Motivational patterns related to gifted students' learning of mathematics, science, and English: An examination of gender differences. Journal for the Education of the Gifted, 18, 284-297. doi: 10.1177/016235329501800305

Litster, K., \& Roberts, J. (2011). The self-concepts and perceived competencies of gifted and non-gifted students: A meta-analysis. Journal of Research in Special Educational Needs, 11, 130-140. doi: 10.1111/j.1471-3802.2010.01166.x

Marsh, H. W. (1986). Self-serving effect (bias?) in academic attributions: Its relation to academic achievement and self-concept. Journal of Educational Psychology, 78, 190-200. doi: 10.1037/0022-0663.78.3.190

Marsh, H. W. (1989). Self-Description Questionnaire (SDQ) III: A theoretical and empirical basis for the measurement of multiple dimensions of late adolescent self-concept: An interim test manual and a research monograph. New South Wales, Australia: University of Western Sydney.

Marsh, H. W. (1990). Influences of internal and external frames of reference on the formation of math and English self-concepts: A multiwave, longitudinal panel analysis. Journal of Educational Psychology, 82, 107-116. doi: 10.1037/0022-0663.82.1.107 
Marsh, H. W., \& Bryne, B. M. (1993). Do we see ourselves as others infer: A comparison of self-other agreement on multiple dimensions of self-concept from two continents. Australian Journal of Psychology, 45, 49-58. doi: 0.1080/00049539308259118

Marsh, H. W., \& O'Neill, R. (1984). Self Description Questionnaire III: The construct validity of multidimensional self-concept ratings by late adolescents. Journal of Educational Measurement, 21, 153-174. doi: 10.1111/j.1745-3984.1984.tb00227.x

Marsh, H. W., \& Shavelson, R. (1985). Self-concept: Its multifaceted, hierarchical structure. Educational Psychologist, 20, 107-123. doi: 10.1207/s15326985ep2003_1

Martin, N. K., \& Dixon, P. N. (1994). The effects of freshman orientation and locus of control on adjustment to college: A follow-up study. Social Behavior and Personality, 22, 201-208. doi: 10.2224/sbp.1994.22.2.201

Mathiasen, R. E. (1985). Characteristics of the college honors student. Journal of College Student Personnel, 26, 171-173.

McCabe, D. L., \& Trevino, L. K. (1997). Individual and contextual influences on academic dishonesty: A multi-campus investigation. Research in Higher Education, 38, 522-538. doi: 10.1023/A:1024954224675

McCabe, D. L., Trevino, L. K., \& Butterfield, K. D. (2001). Cheating in academic institutions: A decade of research. Ethics and Behavior, 11, 219-232. doi: 10.1207/S15327019EB1103_2

Mehta, M. (2009). Importance of relationship between locus of control and academic achievement of senior secondary schools. The Journal of Progressive Education, 2, 75-78.

Miller, A., Shoptaugh, C., \& Parkerson, A. (2008). Under reporting of cheating in research using volunteer college students. College Student Journal, 42, 326-339.

Morrow, K. A. (1989). Locus of control and rural-urban status in gifted high school students. Roeper Review, 11, 207-208. doi: 10.1080/02783198909553212

Murdock, T. B., \& Anderman, E. M. (2006). Motivational perspectives on student cheating: Toward an integrated model of academic dishonesty. Educational Psychologist, 41 129-145. doi: 10.1207/s15326985ep4103_1

Newstead, S. E., Franklyn-Stokes, A., \& Armstead, P. (1996). Individual differences in student cheating. Journal of Educational Psychology, 88, 229-241. doi: 10.1037/0022-0663.88.2.229

Noel, J. G., Forsyth, D. R., \& Kelley, K. N. (1987). Improving the performance of failing students by overcoming their self-serving attributional biases. Basic and Applied Social Psychology, 8, 151-162. doi: 10.1080/01973533.1987.9645882 
Nokelainen, P., Tirri, K., \& Merenti-Välimäki, H. (2007). Investigating the influence of attribution styles on the development of mathematical talent. Gifted Child Quarterly, 51, 64-81. doi: 10.1177/0016986206296659

Owunwanne, D., Rustagi, N., \& Dada, R. (2010). Students' perceptions of cheating and plagiarism in higher institutions. Journal of College Teaching and Learning, 7, 59-68.

Pascarella, E. T., \& Terenzini, P. T. (1991). How college affects students: Findings and insights from twenty years of research. San Francisco, CA: Jossey-Bass.

Pascarella, E. T., \& Terenzini, P. T. (2005). How college affects students: A third decade of research (Vol. 2). San Francisco, CA: Jossey-Bass.

Pavella, G. (1997). Applying the power of association on campus: A model code of academic integrity. Journal of College and University Law, 24, 97-118.

Pearson, K. (1895). Mathematical contributions to the theory of evolution III. Regression, heredity and pan ixia (abstract). Proceedings of the Royal Society of London, 59, 69-71. doi: 10.1098/rspl.1895.0058

Peugh, J. \& Enders, C. (2004). Missing data in educational research: A review of reporting practices and suggestions for improvement. Review of Educational Research, 74, 525-556. doi: $10.3102 / 00346543074004525$

Pino, N W., \& Smith, W. L. (2003). College students and academic dishonesty. College Student Journal, 37, 490-500.

Prihadi, K., \& Hairul, N. I. (2011). How locus of control moderates the effect of perceived teachers' expectancy and self-esteem among high-performing students. Problems of Education in the $21^{\text {st }}$ Century, 34, 110-121.

Pyryt, M. C., \& Mendaglio, S. (1994). The multidimensional self-concept: A comparison of gifted and average-ability adolescents. Journal for the Education of the Gifted, 17, 299-305. doi: $10.1177 / 016235329401700307$

Rettinger, D. A., \& Kramer, Y. (2009). Situational and personal causes of student cheating. Research in Higher Education, 50, 293-313. doi: 10.1007/s11162-008-9116-5

Rinn, A. N. (2005). Trends among honors college students: An analysis by year in school. The Journal of Secondary Gifted Education, 16, 157-167.

Rinn, A. N. (2007). Effects of programmatic selectivity on the academic achievement, academic self-concepts, and aspirations of gifted college students. Gifted Child Quarterly, 51, 232-245. doi: $10.1177 / 0016986207302718$ 
Rinn, A. N., \& Cunningham, L. G. (2008). Using self-concept instruments with high ability college students: Reliability and validity evidence. Gifted Child Quarterly, 52, 232-242. doi: $10.1177 / 0016986208319458$

Rinn, A. N., Plucker, J. A., \& Stocking, V. B. (2010). Fostering gifted students' affective development: A look at the impact of academic self-concept. Teaching Exceptional Children, 6, 2-13.

Rotter, J. B. (1954). Social learning and clinical psychology. Englewood Cliffs, NJ: PrenticeHall. doi: 10.1037/10788-000

Rotter, J. B. (1966). Generalized expectancies for internal versus external control of reinforcement. Psychological Monographs, 80, 1-28. doi: 10.1037/h0092976

Rotter, J. B. (1975). Some problems and misconceptions related to the construct of internal versus external control of reinforcement. Journal of Counseling and Clinical Psychology, 43, 5667. doi: $10.1037 / \mathrm{h} 0076301$

Scheers, N. J., \& Dayton, M. (1987). Improved estimation of academic cheating behavior using the randomized response technique. Research in Higher Education, 26, 61-69. doi: 10.1007/BF00991933

Schunk, D. H. (1991). Self-efficacy and academic motivation. Educational Psychologist, 26, 207-231. doi: 10.1080/00461520.1991.9653133

Shavelson, R. J., Hubner, J. J., \& Stanton, G. C. (1976). Validation of construct interpretations. Review of Educational Research, 46, 407-441. doi: 10.3102/00346543046003407

Siegle, D., \& Reis, S. M. (1998). Gender differences in teacher and student perceptions of students' ability and effort. Gifted Child Quarterly, 42, 39-47. Doi: $10.1177 / 001698629804200105$

Siegle, D., Rubenstein, L. D., Pollard, E., \& Romey, E. (2010). Exploring the relationship of college freshmen honors students' effort and ability attribution, interest, and implicit theory of intelligence with perceived ability. Gifted Child Quarterly, 54, 92-101. doi:

$10.1177 / 0016986209355975$

Sierra, J. J., \& Hyman, M. R. (2006). A dual-process model of cheating intentions. Journal of Marketing Education, 28, 193-204. doi: 10.1177/0273475306291464

Singhal, A. C. (1982). Factors in students' dishonesty. Psychological Reports, 51, 775-780. doi: 10.2466/pr0.1982.51.3.775 
Smith, C. L., Sapp, M., Farrell, Jr., W. C., \& Johnson, Jr., J. H. (1998). Psychoeducational correlates of achievement for high school seniors at a private school: The relationship among locus of control, self-esteem, academic achievement, and academic self-esteem. The High School Journal, 81, 161-166.

Tabachnick, B. G., \& Fidell, L. S. (2007). Using multivariate statistics ( $5^{\text {th }}$ ed.). Boston: Allyn and Bacon.

Trevino, L. K., \& Youngblood, S. A. (1990). Bad apples in bad barrels: A casual analysis of ethical decision-making behavior. Journal of Applied Psychology, 75, 378-385. doi: 10.1037/0021-9010.75.4.378

Vandehey, M., Diekhoff, G., \& LaBeff, E. (2007). College cheating: A twenty-year follow-up and the addition of an honor code. Journal of College Student Development, 48, 468-480. doi: $10.1353 / \mathrm{csd} .2007 .0043$

Weiner, B. (Ed.). (1974). Achievement motivation and attribution theory. Morristown, NJ: General Learning Press.

Weiner, B. (1985). An attributional theory of achievement motivation and emotion. Psychological Review, 92, 548-573. doi: 10.1037/0033-295X.92.4.548

West, T., Ravenscroft, S. P., \& Shrader, C. B. (2004). Cheating and moral judgment in the college classroom: A natural experiment. Journal of Business Ethics, 54, 173-183. doi:

10.1007/s10551-004-9463-X

What is Plagiarism? (n.d.) Retrieved from

http://www.plagiarism.org/learning_center/what_is_plagiarism.html

Whitley, Jr., B. E. (1998). Factors associated with cheating among college students: A review. Research in Higher Education, 39, 235-274. doi: 10.1023/A:1018724900565

Yong, F. L. (1994). Self-concepts, locus of control, and Machiavellianism of ethnically diverse middle school students who are gifted. Roeper Review, 16, 192-194. doi:

$10.1080 / 02783199409553571$ 